\title{
Biophysical and economic models for assessing impacts of change on grazingland ecosystems ${ }^{1}$
}

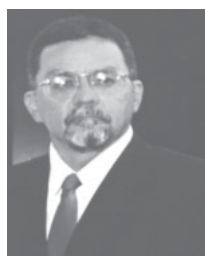

José de Souza Neto² ${ }^{2}$ James R. Conner ${ }^{3} \&$ Jerry W. Stuth ${ }^{4}$

\begin{abstract}
1 Extracted from the first writer's thesis presented to the Texas A\&M University, Texas, USA
2 Embrapa/Agroindústria Tropical. C.P. 3761, CEP 60511-110, Fortaleza, CE. Fone: (85) 299 - 1909. E-mail: jsneto@cnpat.embrapa.br (Foto)

3 Department of Rangeland Ecology and Management, Texas A\&M University, College Station, Texas 77843-2126,

USA. Fone: 979845 - 7456. E-mail: jrc@tamu.edu

${ }^{4}$ Department of Rangeland Ecology \& Management. R\&G Base. Fone: 979845 - 5548. E-mail: jstuth@tamu.edu
\end{abstract}

Protocolo $101-16 / 08 / 2000$

\begin{abstract}
PHYGROW, a hydrologic-based forage simulation model, was parameterized to represent a typical South Texas ranch engaged in the production of cattle and meat goats with an indigenous population of white-tailed deer. Forage production and associated stocking rates for two cattle:goat ratios were simulated with POPMIX for 20 years. Two ten-year weather scenarios, one representing normal conditions ( $30 \%$ drought years) and one representing dryer weather conditions ( $50 \%$ drought years) were analyzed. Management decision rules (ASPC) were developed for the region to produce estimates of annual animal production and operating costs for the enterprises on each of the four scenarios. These performance and cost data were then used as input into FLIPSIM, a firm level income and policy simulator, along with relevant product and input price data for the region. Integration of modeled results produced useful information showing the socioeconomic consequences for a typical South Texas firm impacted by alternative climatic conditions and management strategies.
\end{abstract}

Key words: simulation, model integration, economic impacts, grazingland ecosystems, management strategies

\section{Modelos biofísicos e econômicos para avaliar impactos de mudanças no ecossistema pastagem nativa}

\begin{abstract}
Resumo: Um modelo de simulação de produção de forragem (PHYGROW), foi parametrizado para representar uma fazenda típica no Sul do Texas envolvida com a produção de bovinos, caprinos e de animais silvestres (cervo). A produção de forragem e as taxas de lotação associadas a bovinos e caprinos foram simuladas com POPMIX para o período de 20 anos. Dois períodos de dez anos, um representando condições normais de tempo (30\% da série de anos secos) e outro representando condições de tempo mais secos (50\%) foram analisados. Foram desenvolvidas regras de decisão de manejo (ASPC) para a região visando estimar a produção anual dos animais e custo operacional para as atividades em cada um dos quatro cenários. Os dados de performance animal e de custo foram então usados como input no FLIPSIM, um simulador de renda e de estratégias de manejo a nível de fazenda, juntamente com dados relevantes de produtos e preços para a região do estudo. A integração dos modelos produziu informações úteis e serviu para mostrar as conseqüências socioeconômicas das diferentes condições climáticas e de alternativas estratégias de manejo para uma fazenda típica no Sul do Texas.
\end{abstract}

Palavras-chave: simulação, integração de modelos, impactos econômicos, ecossistema pastagem nativa, estratégias de manejo

\section{INTRODUCTION}

Over the past half-century, a large number of issues related to human use of grazinglands have been analyzed. Many of these analyses, however, have failed to provide the reliability, robustness and usefulness for managers and policy makers that similar efforts directed at agronomic production have produced (Bernardo \& Conner, 1990). Several factors contribute to this analytical difficulty, including the complexity of a system where the product of interest comes from herbivores using grazed forages; the heterogeneity of range ecosystems; the adverse and high variable climatic conditions associated with rangelands; and the difficulty in understanding the underlying ecological forces that govern grazingland productivity. Conner (1994) suggests that assessing the socioeconomic impacts of change (technological, institutional or environmental) on grazinglands could be accomplished using a procedure whereby a region is characterized by modeling a set of representative farms using the output from the plant growth model as input to a firm level economic performance model. The study was conducted to evaluate the use of biophysical and economic models in the grazingland ecosystems change. 


\section{MATERIAL AND METHODS}

Data for a typical South Texas ranch were used to parameterize PHYGROW* (RSG 1995; Stuth et al., 1997). Two cattle:goat ratios, 70:30 and 50:50, were selected to represent alternative management strategies available to a firm operator. Twenty years of simulated forage production and associated stocking rates from PHYGROW were divided into two ten-year periods, one representing a normal climatic scenario with about $30 \%$ drought years, and the other a drier climatic scenario with about $50 \%$ drought years. Drought years were defined as those in which the stocking rate output from PHYGROW was less than $80 \%$ of the long-term average. The stocking rates for the four, ten-year period scenarios were used (POPMIX) with a set of decision rules prescribed by range animal scientists and ranch managers familiar with cattle and meat goat (ASPC) enterprises in the South Texas area to estimate annual animal production levels and deviations from normal (average) annual operating cost for the two enterprises.

The annual animal production levels and operating cost deviations were used as input data in the Firm Level Income and Policy Simulator - FLIPSIM (Richardson \& Nixon, 1986). FLIPSIM is a dynamic, recursive and stochastic model that simulates the impact on the financial and economic characteristics of a specified farm or ranch firm of the alternative institutional, technological or managerial environments over a specified time period (number of years). Product and input prices and annual yields (production

PHYGROW can be used to analyse variation in stocking of representative landscape in any region to determine impact of weather variation on stocking rates of mixed animal populations. Researchers at Embrapa/CPAP have been setting parameters in PHYGROW so that it can account for flooded grasslands. Descriptions of modeling components can be found at the following URL on de World Wide Web: http://ranch.tamu.edu/rsg/phygrow levels) are exogenous to the model and must be specified by the user, either by directly entering annual values or prescribing a probability distribution from which annual values may be randomly sampled. In this study, product and input prices parameters for the South Texas representative farm were obtained from the FAPRI/AFPC Baseline 1996 database ${ }^{* *}$. The use of PHYGROW to provide forage production, POPMIX to provide stocking rates (vegetative consumption), an Animal Production Spreadsheet Calculator - ASPC to provide animal performance and production data, which altogether provided appropriate input data for assessing socioeconomic interrelationships. These models are appropriate for initializing an integrated model and show that species composition (plant and animals) can be integrated into the assessment of socioeconomic impacts of environmental or other changes on rangelands.

The input of PHYGROW, POPMIX, and ASPC will create the basic scenarios for the representative farm, for which economic performance will be simulated by FLIPSIM. At the farm level, forage production were predicted to provide inputs into a whole-farm economic impact model. This whole-farm model is needed because it allows the incorporation of risk and uncertainty, financial and accounting components, and institutional farm policies into the calculations of economic performance of the farm.

The FLIPSIM model will run in stochastic mode, and consequently provide outcomes for analyzing alternative management strategies and determining their effects on the economic feasibility of the representative farm under alternative scenarios (Souza Neto, 1996).

The models work independently, and are controlled by the analyst. The interrelations between the models to perform this study are included in Figure 1.

"* Richardson, J.W. Personal communication. Texas A\&M University, College Station, Texas, 1996

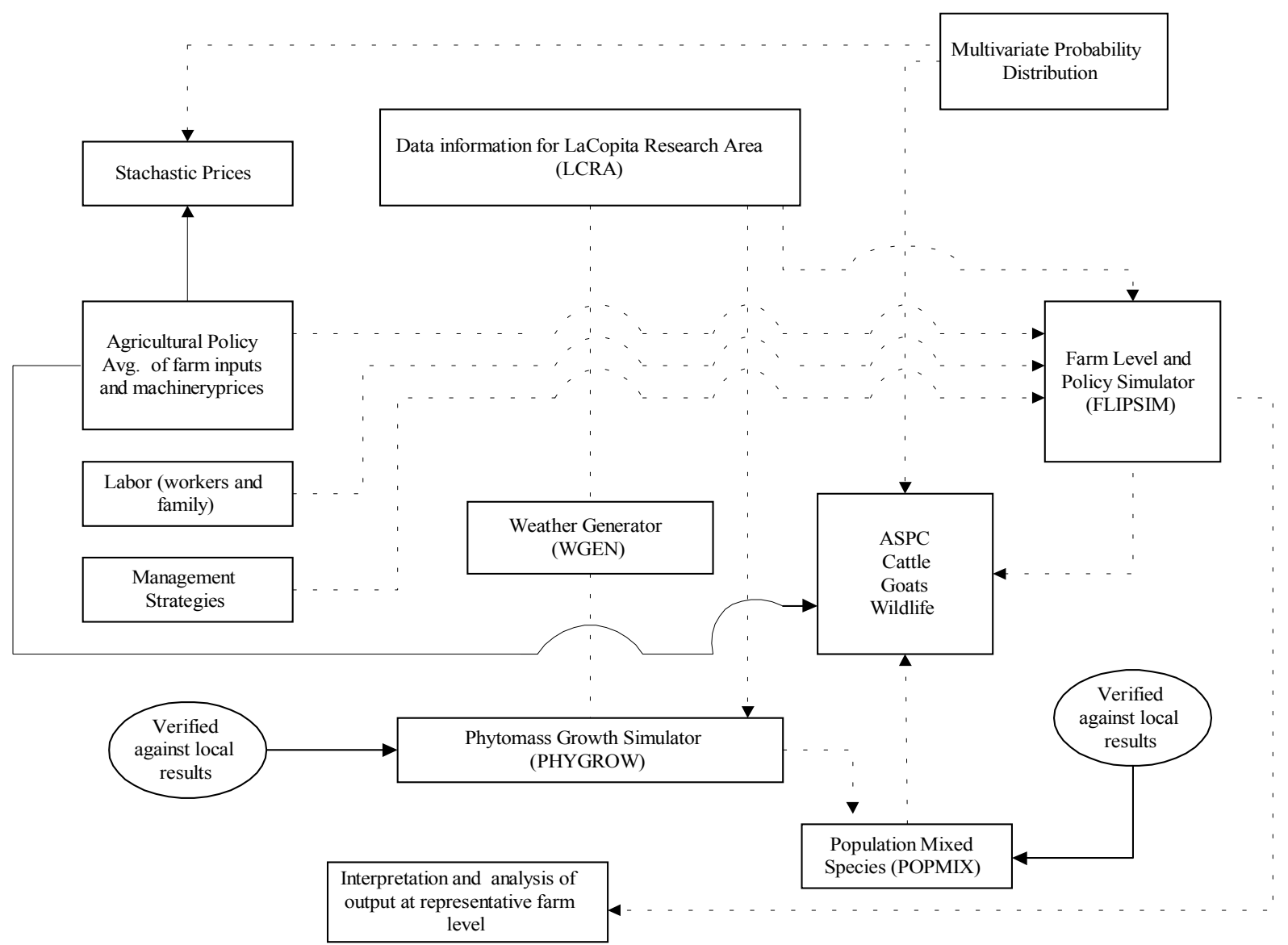

Figure 1. Framework for integrating ecological and socioeconomic models 


\section{RESULTS AND DISCUSSION}

A summary of selected indicators of the economic and financial condition of the representative farm that would be expected after ten years under each of the four prescribed scenarios can be found in Table 1. Under the normal weather scenario, the 70:30 cattle:goat ratio produces less decline in real net worth, higher average annual cash receipts and net income but lower average annual returns to assets and equity and a higher net income risk index than does the 50:50 ratio. The net income risk index indicates the probability that net income in any given year will not be sufficient to meet required expenses thus resulting in an increase in debt.

Table 1. Implications of alternative stocking rate for a South Texas cattle goats farm under two climate scenarios*

\begin{tabular}{|c|c|c|c|c|}
\hline \multirow{3}{*}{ Cattle:Goat ratio } & \multicolumn{4}{|c|}{ Weather } \\
\hline & \multicolumn{2}{|c|}{ Dry } & \multicolumn{2}{|c|}{ Normal } \\
\hline & $70: 30$ & $50: 50$ & $70: 30$ & $50: 50$ \\
\hline \multicolumn{5}{|l|}{ Change in Real Net } \\
\hline Worth 1996-2005 (\%) & -2.65 & -2.90 & -2.12 & -2.46 \\
\hline \multicolumn{5}{|l|}{ Cash Receipts } \\
\hline $1996-2005(\$ 1000)$ & 220.57 & 211.54 & 225.97 & 218.37 \\
\hline \multicolumn{5}{|l|}{ Expenses to Receipt } \\
\hline $1996-2005(\%)$ & 50.90 & 49.60 & 47.10 & 46.19 \\
\hline \multicolumn{5}{|l|}{ Net Cash Farm Income } \\
\hline $1996-2005(\$ 1000)$ & 110.72 & 108.60 & 122.19 & 119.75 \\
\hline \multicolumn{5}{|l|}{ Risk Index for Annual } \\
\hline Net Cash Income (\%) & 14.95 & 9.96 & 2.00 & 0.00 \\
\hline \multicolumn{5}{|l|}{ Average Return to Assets } \\
\hline $1996-2005(\%)$ & 0.48 & 0.57 & 0.50 & 0.59 \\
\hline \multicolumn{5}{|l|}{ Average Return to Equity } \\
\hline $1996-2005(\%)$ & 0.40 & 0.53 & 0.43 & 0.55 \\
\hline
\end{tabular}

Under the dryer weather scenario, declines in real net worth are greater, cash receipts, net income and returns to assets and equity are lower regardless of cattle:goat ratio than under the normal weather scenario. As in the normal weather scenario, however, the 70:30 cattle:goat ratio produces higher receipts and net income risk index than the 50:50 ratio.

The results are indicative of the fact that in this region, goats, while generally less profitable than cattle, require less annual operating cost, less capital investment and exhibit less variation in annual receipts and net income. The lower variation in net incomes from goats compared to cattle is due both to the goats' forage availability being less impacted by variations in annual precipitation and to less year to year change in prices received for meat goats compared to weaned calves sold from cow-calf enterprises.

\section{CONCLUSIONS}

1. The study illustrates that useful results can be achieved by incorporating ecological and socioeconomic models.

2. The framework developed herein represents an evolutionary effort in the task of streamlining and refining our ability to adequately assess the ecological and socioeconomic impacts of change on grazingland ecosystems.

3. The study offers evidence that efforts to develop truly integrated models, where the impacts of socioeconomic actions on the grazingland ecosystem could also be internalized and accounted for, should be continued.

\section{ACKNOWLEDGEMENTS}

We wish to express gratitude to Professors Dr. Wayne Trevor Hamilton, Dr. James Willis Richardson and Dr. José Ednilson de Oliveira Cabral, for their valuable suggestions, without their support would not have been possible to finalize this paper.

\section{LITERATURE CITED}

Bernado, D.J.; Conner, J.R. Contemporary methodologies in range economics Corvaillis research. In: Obemiller, F.W. (ed). Current issues in rangeland resource economics. Oregon State University Extension Service. 1990. 24-24p. Special Report 852.

Conner, J.R. Assessing the socio-economic impacts of climate change on grazinglands. In: Frederick, K.D.; Rosemberg, N.J. (eds). Climatic Change, v.28, p.143-157,1994.

Ranching Systems Group (RSG). PHYGROW, College Station, Texas: - An object oriented hydrologic based, multispecies forage production model. Ranching Systems Group Document 95-1. Department of Rangeland Ecology and Management, Texas A\&M University. $1995.47 \mathrm{p}$.

Richardson, J.W.; Nixon, C.J. Description of FLIPSIM-V: A general firm level policy simulation model. College Station, Texas: Texas Agricultural Experiment Station Bulletin 1528. 1986. 178p.

Souza Neto, J. de. Integrating ecological and economic models for assessing institutional, environmental and technological change on rangeland. College Station, Texas: Department of Rangeland Ecology and Management, Texas A\&M University. 1996. 165 p.

Souza Neto, J. de.; Conner, J.R.; Stuth, J.W.; Hamilton, W.T.; Richardson, J.W. Management strategies and climate impact change on rangelands. Pesquisa Agropecuária Brasileira, Brasília, v.33, n.9, p.1533-1541, 1998.

Stuth, J.W.; Conner, J.R.; Hamilton, W.T.; Schmitt, D.M. Application of the PHYGROW forage production-runoff model for regional stocking analysis. Proc. International Grassland Congress, 18. Winnipeg, Manitoba: Saskatoon, Saskatchewan. 1997. 6p. 